\title{
Opinion of the members towards Self-help group
}

\author{
RULI DAULAGUPU, MINERVA SAIKIA BARUAH AND MANJU DUTTA DAS
}

Received: 27.02.2015; Accepted: 30.05 .2015

See end of the paper for authors' affiliations RULI DAULAGUPU Department of Extension Education, College of Home Science, Assam Agricultural University, JORHAT (ASSAM) INDIA
ABSTRACT : Formation of self-help group is a viable alternative to achieve the objectives of rural development and to get community participation. So this study was conducted to determine the opinion of the respondents self-help group members towards SHG. Two block from Jorhat district were purposively selected to carry out the study namely Jorhat development block and Central Jorhat development block. It was revealed that Majority (64.00\%) of the respondents of SHG expressed their opinion towards SHG as highly favourable followed by 34.00 per cent as favourable and small portion of respondents (3.00\%) expressed their opinion towards self-help group as unfavourable. The findings showed that majority of SHGs were active. As the researcher selected active SHG's for present study hence, the respondent of SHGs were highly favourable towards SHG.

KEY WORDS: Opinion, Self-help group, Member

- HOW TO CITE THIS PAPER : Daulagupu, Ruli, Baruah, Minerva Saikia and Das, Manju Dutta (2015). Opinion of the members towards Self-help group. Asian J. Home Sci., 10 (1) : 265-268. 